\title{
Professional Growth and Advancement and Research- Based Teaching Innovations of Elementary School Teachers
}

\author{
Julie Pearl C. Ortiz*, Alvic A. Arnado, PhD.** \\ juliepearl.ortiz@ deped.gov.ph* aaarnado@carsu.edu.ph ** \\ Balangbalang Elementary School, Agusan del Norte Division* \\ Caraga State University, Ampayon, Butuan City**
}

DOI: 10.29322/IJSRP.12.01.2022.p12137

http://dx.doi.org/10.29322/IJSRP.12.01.2022.p12137

\begin{abstract}
The primary goal of the study is to determine the professional growth and advancement of public elementary school teachers and their research-based teaching innovations, and the extent of their educational preparation, in-service education, and individual performance commitment review. The results revealed that most elementary school teachers are continuing their graduate studies in masters and even in a doctorate degree. As to the teachers' professional growth and advancement which manifests as highly proficient teachers consistently displaying a high level of performance in their teaching practice which manifests the in-depth and sophisticated understanding of the teaching and learning process. However, teachers were given limited exposures to pieces of training related to research resulting in only meager numbers were able to conduct research such as science investigatory project (SIP), action research, strategic intervention materials (SIM), and improvised materials either presented in at most national level and/or published in non-refereed journals. The developed instructional materials were utilized in teaching. The IPCRF of the teachers showing outstanding performance represents an extraordinary level of achievement and commitment. Results also revealed that there is no significant relationship between professional growth and advancement and their teaching performance. Moreover, predicting teaching performance has no significant influence on the professional growth and advancement of elementary school teachers.
\end{abstract}

Keywords: professional growth and advancement, research-based teaching innovations

\section{INTRODUCTION}

Teachers should become research-conscious to gain social, economic, cultural, and political benefits. Education has great importance in building strong and developed societies. Teachers are required to be professionally developed in terms of individual development, continuing education, in-service education, curriculum writing, peer collaboration, study groups, and peer coaching or mentoring.

In the Philippines, the development of research competence among teachers is emphasized in the continuing education program of the Department of Education. All teachers are encouraged to engage in research as evidenced by the additional points for the ranking in the promotion process. The enclosed policy also improves support mechanisms for research like funding, partnerships, and capacity building. Continuous Professional Development (CPD) is supposed to prepare teachers for research.

In the case of R.T. Romualdez District under the Division of Agusan del Norte, composed of nine elementary schools, the research development program for teachers includes school in-service training in the conduct of action research. The goal is to enhance the capability of the teachers while addressing classroom-based problems school and come up to design a model to have a positive outcome for the teachers. Moreover, the district is consistently sending participants to seminars on research and to science fairs that showcase classroom teachers doing investigatory projects, intervention materials, and improvised materials. However, common knowledge still reveals the scarcity of teachers involved in research activities and limited research outcomes. Hence, this study is purposed to design a model with an effectual strategy of teacher upgrading to enhance the research competence of elementary teachers and to find out the performance of the elementary teachers in the district in doing research.

\section{The Objectives of the Study}

The study determines teachers' professional development and advancement and research-based teaching innovations of the elementary school teachers of R. T. Romualdez (RTR) District Division of Agusan del Norte. Specifically, to identify the extent of the elementary school teachers of RTR district in terms of educational preparations: highest educational attainment, program accreditation, and nature of degree, to determine the extent of the professional growth and advancement among elementary school teachers of RTR district in terms of: philosophy of teaching, dignity of teaching as a profession, professional links with colleagues, professional reflection and learning to improve practice, and professional development goals, in-service education: nature of learning, scope of learning, peer collaboration, peer coaching and, study groups, to ascertain the level of research innovation of the elementary school teachers of RTR district in terms of: research production as to the number of research conducted, role in the research conducted, as well as the nature of research funds; research publication scope of papers presented, as well as scope of publication ; utilization of researched based instructional materials, to determine the level of teachers teaching performance of the elementary school teachers, to examine if there a significant relationship between professional growth and advancement and the teaching performance based on IPCRF, to test what educational preparation best predict the career stage of elementary school teachers, to propose capability building enhancement based on the findings of the study.

Framework of the Study 
This study is an anchor with the Magna Carta for Public School Teachers in Republic Act 4670, Article IV, and Section 3 states that all officials and teachers must aspire to widen their cultural horizons and hone their professional skills. They should pursue further studies to improve efficiency and enhance the profession's prestige.

The Department of Education (DepEd) understands the importance of professional standards in teachers' ongoing professional development and growth. To ensure that teachers are fully qualified to implement the K-12 Program, the PPST will serve as the foundation for all teacher learning and development activities.

The Strategic Development Framework (SDF) also added that continuous improvement of the competencies of teaching staff is required. Professional development refers to activities that will enhance professional career growth. Individual development, continuing education, in-service education, and peer collaboration are examples of such activities.

The Governance of Basic Education Act of 2001 (R.A. 9155) requires the Department of Education to create policies and methods that will allow for the ongoing improvement of education delivery. The undertaking of "educational research and studies" that would serve as one of the foundations for critical reforms and policy formulation is one of the obligations of DepEd across all governance levels, according to Chapter 1, Section 7 (5). (Department of Education Order No. 16, Section 2017)

Abraham Maslow's self-actualization is on research on healthy and mature persons. It highlights the individual's uniqueness and the capacity for self-direction and improved functioning. People are motivated to seek personal objectives that make their life meaningful and satisfying.

Based on the theories presented, the following conceptual framework of the study. The dependent variables are the research innovation, research dissemination, and utilization of researched-based instructional materials educational process improved using research outputs, research outputs packaged. The policy built on the gains in evidence-based decision-making from various education reforms or initiatives shall strengthen the culture of research in the Department. The independent variables are the level of professional growth, advancement, and the educational preparation of teachers.

\section{Methodology}

The study employed descriptive since it utilized cross-sectional data - information limited only to the time gathered. Descriptive design is used in finding the professional growth, research innovations, and the teaching-learning process of elementary school teachers. Correlation design is used to determine if the professional growth and advancement building experienced by the teachers influenced their capacity in doing research, disseminating research outputs, and utilizing research outputs and their teachinglearning output. The respondents considered the elementary school teacher of Remedios T. Romualdez District of Agusan del Norte division. The research instrument used is a modified standardized questionnaire in gathering the data. The said instrument makes use of PPST components. It is divided into four sections. Part 1 is a profile of the teachers in terms of their educational preparation, and Part 2 focuses on the teachers' professional growth and advancement in PPST domain seven (7) and in-service education, Part 3 on the research innovation, and part 4 for the performance and commitment review. The study used the following statistical tools; Frequency Counts, Percentage, Weighted Mean, and Standard Deviation used to describe the extent of elementary school teachers' educational preparation, professional growth and advancement and in-service education, research innovation, and teachers individual performance. Based on IPCRF, Pearson $r$ was used to indicate if there is a significant relationship between the participant's professional growth and advancement and their teaching performance. Regression Analysis is applied to determine to what extent each of the participants, singly or in combination, may predict the performance of the teachers.

\section{Results and Discussion}

\section{Highest Educational Attainment}

It's about $43.16 \%$ (or 41 ) of teachers had their baccalaureate degree with units earned in masters, and only about $2.11 \%$ (or 2) had their full-fledged doctorate holder. In addition, one-third (31.58\% or 30) had their full-fledged master's degree.

Table 2. Frequency and percentage distribution of the participant's highest educational attainment

\begin{tabular}{|c|c|c|}
\hline $\begin{array}{r}\text { Highest Educational Attainment } \\
\end{array}$ & Frequency & Percentage \\
\hline Baccalaureate degree & 19 & 20.00 \\
\hline Baccalaureate degree with units earned in masters & 41 & 43.16 \\
\hline Master's degree & 30 & 31.58 \\
\hline Master's degree with earned units in doctorate & 3 & 3.16 \\
\hline Doctorate degree & 2 & 2.11 \\
\hline
\end{tabular}

This further implies that more than one-third $(36.84 \%)$ of the participating teachers were involved in doing research, especially in their graduate studies experiences. This indicates that the elementary school teachers of RTR considered graduate studies as a credible path towards professional development. This is supported by the study of Bueno and Basilio (2019), who reiterated that teachers have high regard relative to the value of doing research to become a better educator. It took time, effort, and resources to learn about study findings and develop good attitudes about research.

\section{Philosophy of Teaching}

Table 5. Frequency and percentage distribution on the classification of teachers in terms of philosophy of teaching

\begin{tabular}{lcc}
\hline \hline Philosophy of Teaching & Frequency & Percentage \\
\hline Beginning Teachers & 5 & 5.26 \\
Proficient Teachers & 33 & 34.74 \\
Highly Proficient Teacher & 42 & 44.21 \\
Distinguished Teachers & 15 & 15.79 \\
\multicolumn{1}{r}{$n=95$} & & \\
\hline \hline
\end{tabular}


This implies that elementary teachers demonstrate a learner-centered philosophy in various ways. A teaching philosophy is a personal undertaking that draws on one's educational experiences. Successful educational reform will significantly improve and sustain learning for students and teachers. Professional learning that focuses on contextually based; personalized, data-driven instruction is critical.

\section{The dignity of teaching as a Profession}

Table 6 shows the frequency and percentage distribution on the classification of teachers in terms of the dignity of teaching as a profession. This study reveals that most of the teachers were classified as highly proficient (about 44.21\%), proficient teacher $(30.25 \%)$, distinguished teacher $(18.95 \%)$, and beginning teacher $(7.37 \%)$.

Table 6. Frequency and percentage distribution on the classification of teachers in terms of the dignity of teaching as a profession

\begin{tabular}{|c|c|c|}
\hline Dignity of Teaching as a Profession & Frequency & Percentage \\
\hline Beginning Teachers & 7 & 7.37 \\
\hline Proficient Teachers & 28 & 29.47 \\
\hline Highly Proficient Teacher & 42 & 44.21 \\
\hline Distinguished Teachers & 18 & 18.95 \\
\hline$n=95$ & & \\
\hline
\end{tabular}

This study indicates that one-half (44.21\%) of the teacher's dignity of teaching as a profession notify a highly proficient teacher. This means that teachers display a high-level performance in their teaching practice and uphold the dignity of teaching as a profession to help build positive teaching and learning culture in school.

The teaching profession is an important concern because all teachers must work, and their labor plays a key role in the survival of many people. Teachers have a responsibility to themselves and to their profession, to deepen their knowledge, extend their professional skills, and keep themselves up-to-date on major development affecting their profession., Nenty, H. J., Moyo, S., \& Phuti, F. (2015).

\section{Professional Links with Colleagues}

Table 7 shows the frequency and percentage distribution on the classification of teachers in terms of professional links with colleagues. As exhibited in this table, about $47.37 \%$ classify highly proficient teachers, $(32.63 \%)$ as proficient teachers, distinguished teachers about $(20.00 \%)$ and the beginning teachers is $(56.32 \%)$ classification according to professional links with colleagues. This implies that teachers are highly proficient in working collaboratively with their colleagues and providing support and mentoring to enhance their learning and practice.

Table 7. Frequency and percentage distribution on the classification of teachers in terms of professional links with colleagues

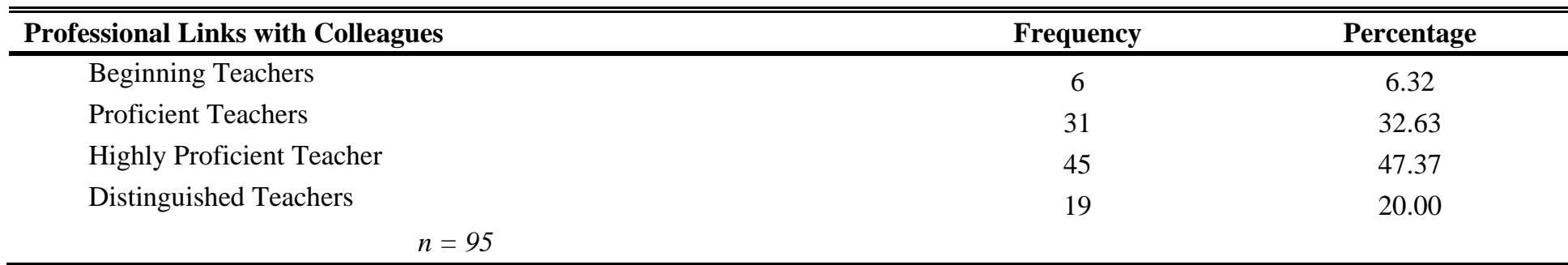

Horn et al. (2020) discovered that teachers' engagement in learning-rich, in-depth meetings highly predicted the new adviceseeking relationships. Furthermore, these new informal links were associated with increased teacher expertise, indicating that teachers' participation in high-depth teacher collaboration had contributed value.

\section{Professional Reflection and Learning to Improve Practice}

Table 8 presents the frequency and percentage distribution on the classification of teachers in terms of professional reflection and learning to improve practice.

As unveiled in table 8 , it brings to light that the majority $(51.58 \%)$ of the teachers exhibit highly proficient in their career stage, $(31.58 \%)$ proficient teacher, $(9.47 \%)$ in the distinguished teacher and scanty $(7.37 \%)$ for the beginning teachers. It indicates that the teachers value personal and professional reflection and learning to improve practice. Furthermore, they improve their professional knowledge and practice by reflecting on their own and their colleagues' and students' needs.

Table 8. Frequency and percentage distribution on the classification of teachers in terms of professional reflection and learning to improve practice

\begin{tabular}{|c|c|c|}
\hline Professional Reflection and Learning to Improve Practice & Frequency & Percentage \\
\hline Beginning Teachers & 7 & 7.37 \\
\hline Proficient Teachers & 30 & 31.58 \\
\hline Highly Proficient Teacher & 49 & 51.58 \\
\hline Distinguished Teachers & 9 & 9.47 \\
\hline$n=95$ & & \\
\hline
\end{tabular}


To develop as a teacher, one must reflect on their experiences or activities. Reflection is a flashback that teachers must mediate to advance their careers. Teachers will be able to deal with the needs and issues of their students if they reflect on their daily teaching-learning activities for professional growth, Mathew, P., Mathew, P., \& Peechattu, P. J. (2017).

According to Burchell, H., Dyson, J., \& Rees, M. (2002) is to value the unique approach adopted by each teacher in seeking to bring about development in practice. Requires a course provider to develop a system that enables teachers to create and follow such individual routes without constraining them to work within a particular model.

\section{Professional Development Goals}

Table 9 presents the frequency and percentage distribution on the classification of teachers in terms of professional development goals.

Table 9. Frequency and percentage distribution on the classification of teachers in terms of professional development goals

\begin{tabular}{|c|c|c|}
\hline Professional Development Goals & Frequency & Percentage \\
\hline Beginning Teachers & 9 & 9.47 \\
\hline Proficient Teachers & 34 & 35.79 \\
\hline Highly Proficient Teacher & 38 & 40.00 \\
\hline Distinguished Teachers & 14 & 14.74 \\
\hline$n=95$ & & \\
\hline
\end{tabular}

As shown in the table above, shows the majority (40.00\%) are highly proficient, proficient teachers (35.79\%), following the distinguished teacher (about $14.74 \%$ ) and the beginning teacher $(9.47 \%$ ) as they have shown as a professional development goal. The implication to the teacher professional development goals and assist colleagues in planning and achieving their goals.

According to the study, if teachers' learning processes lead to school improvement, they must be developed. In addition to studying learning processes in schools, researchers must conduct formative intervention studies. Finally, researchers should stimulate and sustain an expanded transformation process led by and owned by the leaders and teachers across the entire school while researching these processes. ( Postholm, 2018).

\section{Nature of Learning}

Table 10 present the frequency and percentage distribution of the in-service education of the participants in terms of its nature of learning.

As exhibited in table 10, shows that about $84.21 \%$ (or 80 ) elementary school teachers attend seminar-workshop and scanty of $3.16 \%$ (or 3 ) attend short term courses. Furthermore, this shows that three-fourth $(84.21 \%$ ) of elementary school teachers joined seminar workshops as the nature of the training they attended. This indicates that teachers have more exposure to seminar workshops.

Table 10. Frequency and percentage distribution on the in-service education of the participants in terms of its nature of learning

\begin{tabular}{cccc}
\hline \hline Nature of Learning & Frequency & Percentage \\
\hline Seminar workshop & & 80 & 84.21 \\
Conference & $n=95$ & 12 & 12.63 \\
Short term course & 3 & 3.16
\end{tabular}

Pre-service should not be overstated because it is critical to education. Need for improving the work performance and motivation of field teachers. Seminars, workshops, conferences, lectures, and exhibitions, for example, are examples of in-service education activities aimed to develop and improve personnel in an organization from the beginning of their employment, Osamwonyi (2016).

\section{Scope of Learning}

Table 11 present the frequency and percentage distribution on the in-service education of the participants in terms of its scope of learning.

Table 11. Frequency and percentage distribution on the in-service education of the participants in terms of its scope of learning

\begin{tabular}{|c|c|c|}
\hline Scope of Learning & Frequency & Percentage \\
\hline Local & 64 & 67.37 \\
\hline Regional & 21 & 22.11 \\
\hline National & 10 & 10.53 \\
\hline & & \\
\hline
\end{tabular}

As shown in the data, elementary school teachers had more exposure to local seminar-workshop. In particular, the data reveal limited exposure to national and international training and even on regional workshops of the teachers.

About $67.37 \%$ (or 64) only trained seminar-workshop in local venues such as schools, districts, and divisions, and $10.53 \%$ (or 10) teachers trained at the national venue. They focused on training wherein the teacher used these activities for the competition in the division or even in the regional arena. This finding implies that the teachers have limited access to training due to budget constraints. It is a sustained focus over time that is consistent with best practice professional development, according to Elemore (2002), is a sustained focus over time that is consistent with best practice. In addition, Van der Klink, M., Kools, Q., Avissar, G., White, S., \& 
ISSN 2250-3153

Sakata, T. (2017) share from their study that participants were currently attending (or had recently been involved in) learning activities such as training courses, seminars, workshops, conference, about to wide range of subjects, varying from teaching specific to the use of information and communication technologies and pedagogical and general teaching skills.

\section{Number of Research Conducted}

Table 15 presents the frequency and percentage distribution of the number of research conducted by the participants.

Data reveals that teachers that were elementary teachers who conducted Science Investigatory Project (SIP) 2,3 or 4 outputs with the frequency of 50 types of research (34.01\%), action research with the frequency of 46 (about 31.29\%), Strategic Intervention Materials (SIM) with the frequency of $25(17.01 \%)$ and improvised materials (17.69\%). It implies that the number of research conducted on some teachers are commonly on SIP, SIM and IMs related to the yearly science activity in the school, district, and even regional competition.

Table 15. Frequency and percentage distribution on the number of research conducted by the participants

\begin{tabular}{lcc}
\hline \hline Number of Research Conducted & Frequency & Percentage \\
\hline SIP & 50 & 34.01 \\
Action Research & 46 & 31.29 \\
SIM & 25 & 17.01 \\
Improvised materials & 26 & 17.69 \\
& Total & $\mathbf{1 4 7}$ \\
\hline \hline
\end{tabular}

The results suggest the study of Hannay, L. M., Seller, W., \& Telford, C. (2003). This study investigated action research as an alternative, collaborative approach for teacher performance appraisal focused on professional growth. Teachers who participated in the project completed their action research and papers as the basis for their necessary performance evaluations.

\section{Level of teachers teaching performance of the elementary school teachers}

Table 21 presents the frequency and percentage distribution of the teaching performance of the elementary school teachers based on their IPCRF.

The education authority department in Indonesia is still working to improve educational quality. It must be by the role of parties, one of which is the teaching staff. According to a 2011 poll conducted by the United Nations Educational Scientific and Cultural Organization (UNESCO), Indonesia's education is in critical condition, with the quality of education in developing countries ranking Indonesia 10th out of 14 countries in the Asia Pacific, and teacher quality ranking last, Andriani, S., Kesumawati, N., \& Kristiawan, M. (2018).

Table 21. Frequency and percentage distribution of the teaching performance of the elementary school teachers based on their IPCRF

\begin{tabular}{cccc}
\hline Range & Frequency & Percentage & Adjectival Rating \\
\hline $4.500-5.000$ & 83 & 69.75 & Outstanding \\
$3.500-4.499$ & 35 & 29.41 & Very Satisfactory \\
$2.500-3.499$ & 1 & 0.84 & Satisfactory \\
$1.500-2.499$ & 0 & 0.00 & Unsatisfactory \\
Below 1.499 & 0 & 0.00 & Poor
\end{tabular}

It is evident that the performance is majority $(69.75 \%)$ indicated as Outstanding and (about $29.41 \%$ ) were very satisfactory and $(.84 \%)$ satisfactory. It demonstrates teachers perform admirably in the classroom, and their extracurricular activities and interactions with students and colleagues.

According to Andriani (2018), a study shows that teacher competency and performance in Indonesia are still insufficient to produce excellent graduates. This research begins from Werang's research in 2014 that examines the several factors that determine the quality of the teacher performance. Transformational leadership is one of the most aspects that affect the success of the teachers. In terms of measures to improve teacher performance, the professional headmaster will consider some of the suggestions made by Sallies Mulyasa (2006).

Furthermore, DepEd Order No. 2, s. 2015 The project should be evaluated using indicators and measurements. Outstanding performance exceeding targets by $30 \%$ and above-planned targets on the Very Satisfactory scale. Unsatisfactory performance falls between 51-99 percent of the planned targets, and Poor-performance is short of anticipated goals.

\section{Analysis of the correlation between the professional growth and advancement and the teachers teaching performance based} on IPCRF

Table 22 presents the correlation analysis of the participants' professional growth and advancement and their teaching performance based on IPCRF.

The obtained data shows that philosophy of teaching ( $p$-value $=0.189)$, dignity of teaching as profession $(p$-value $=0.460)$, professional links with colleagues $(\mathrm{p}$-value $=0.446)$, professional reflection and learning improve practice $(\mathrm{p}$-value $=0.198)$ and professional goals ( $\mathrm{p}$-value $=0.110$ ) are found to have no significant relationship to the Individual Performance and Commitment Review Form (IPCRF). Meaning, all extent of professional growth and advancement has a low negative correlation $(\mathrm{R}-\mathrm{values}=-$ $0.121,-0.068,-071,-0.119,-0.147$, respectively).

Table 22. Correlation analysis of the participants' professional growth and advancement and their teaching performance based on IPCRF? 
Teaching Performance

Professional Growth and advancement

- Philosophy of teaching

- Dignity of teaching as a profession

$-0.068$

- Professional links with colleagues

$-0.071$

- Professional reflection and learning to improve practice

$-0.119$

- Professional development goals

$-0.147$

0.110

Level of significance: $\alpha=.05^{*}$

Performance appraisal has often portrayed as temporally constrained (Acheson \& Gall, 1992; Darling-Hammond \& McLaughlin, 1995; Falk \& Ort, 1998) because the contractual necessity often involves a supervisor assessing a teacher performance through one or several classroom observations.

Teachers gain confidence in their future performance when they believe that their efforts, even in the face of adversity, have aided children in learning. Teacher efficacy refers to a set of beliefs regarding a teacher's capacity to motivate students to learn. It is tailored to teach specific topics to individual students in certain learning environments, Ross \& Mcdougall, (2003).

\section{Educational preparation best predicts the teaching performance of elementary school teachers?}

The direct effects have been hypothesized and tested through regression analysis namely; the philosophy of teaching, the dignity of teaching as a profession, professional links with colleagues, professional reflection and learning to improve practice, and the professional development goals and teaching performance of public elementary school teachers. R square statistics show whether there is satisfactory variability caused by independent variables on dependent variables even beta values predicted showcase strong changes in independent variables. In a general sense, beta value interpreted by 1 , unit change in the independent variable, due to change in the dependent variable.

Tables 23 shows the R-square statistic, which is 0.028 . It means that professional growth and advancement indicators have a $2.8 \%$ impact on the extent of the teaching performance of elementary school teachers. Moreover, the significance value $(\mathrm{P}-\mathrm{V}$ alue $)$ of each of the indicators: philosophy of teaching $(p=0.721)$, the dignity of teaching as a profession $(p=0.782)$, professional links with colleagues $(p=0.626)$, professional reflection, and learning to improve practice $(p=0.555)$, and professional development goals $(p=$ $0.319)$ are less than the level of significance $(\alpha=0.05)$ which confirms the rejection of the hypothesis undertaken.

Table 23. Regression analysis summary predicting teaching performance of the participants

\begin{tabular}{|c|c|c|c|c|c|}
\hline Variables & B & SE & $\boldsymbol{\beta}$ & $\mathbf{t}$ & $p$ \\
\hline (Constant) & 4.857 & .241 & & 20.16 & .000 \\
\hline - Philosophy of teaching & -.035 & .097 & -.053 & -.358 & .721 \\
\hline $\begin{array}{l}\text { - Dignity of teaching as a } \\
\text { profession }\end{array}$ & .025 & .090 & .040 & .277 & .782 \\
\hline $\begin{array}{l}\text { - Professional links with } \\
\text { colleagues }\end{array}$ & .045 & .092 & .071 & .489 & .626 \\
\hline $\begin{array}{l}\text { - Professional reflection and } \\
\text { learning to improve practice }\end{array}$ & -.057 & .097 & -.088 & -.592 & .555 \\
\hline $\begin{array}{c}\text { - Professional development goals } \\
R^{2} \\
F\end{array}$ & $\begin{array}{l}-.079 \\
0.028 \\
0.649\end{array}$ & .079 & -.128 & -1.002 & .319 \\
\hline
\end{tabular}

a. Dependent Variable: Teaching performance

The result shows that no variable among the indicators of professional growth and advancement predicts elementary school teachers' performance, possibly because there is something in developing the evaluation that needs to be aligned with the newly implemented Philippine Professional Standards for Teachers (PPST) indicators of professional growth and advancement.

It is validated by Goe, Biggers, and Croft (2012) that developers should carefully consider the types of evidence required to assess teachers' performance against the teaching standards. They can then decide what measures to use to collect the data once they've agreed on the categories of proof needed for an evaluation system.

Furthermore, in the study of Pearson, J. A. (2016), teacher educators' professional growth includes a variety of styles of learning, ranging from implicit learning to conscious activities to improve one's competencies. Smith (2003) professional development activities are thought to diverse and include formal and informal, individual, and team-based and individual and group-based ones. Participation in seminars and workshops, professional development, and criticism of one's teaching are all options.

\section{Conclusion and Recommendation}

The teacher participants considered graduate studies as a credible path towards professional development. They have limited exposure to national and international training and even regional training. Moreover, no variable predicts the teaching performance of elementary school teachers in the Philippines.

Based on the findings, it is recommended to upgrade the professional growth of the teachers, encourage teachers to participate in training in regional /national to have more exposure in training in research-related training, and enhance the research innovation of the elementary school teachers.

\section{References}

Achwarin, N. A. (2009). The study of teacher competence of teachers at schools in the three southern provinces of Thailand. Scholar: Human Sciences, 1(1). http://www.assumptionjournal.au.edu/index.php/Scholar/article/view/874 
ISSN 2250-3153

Almonte-Acosta, S. A. (2007). Developing Research Culture in Philippine Higher Education Institutions: Perspectives of University Faculty Rose Marie SalazarClemeña, PhD Dean, College of Education De La Salle University-Manila. PhD Dean, College of Education De La Salle UniversityManila.https://doi.org/10.1.1.535.5909

Andriani, S., Kesumawati, N., \& Kristiawan, M. (2018). The influence of the transformational leadership and work motivation on teachers performance. International Journal of Scientific \& Technology Research, 7(7), 19-29.

Bare, A. S., \& Douglas, L. (1934). The pre-training selection of teachers. The Journal of Educational Research,28(2), 92-117. , DOI: $\underline{10.1080 / 00220671.1934 .10880467}$

Basilio, M. B., \& Bueno, D. C. (2019). Research Skills and Attitudes of Master Teachers in a Division Towards Capability Training. In 19th CEBU Philippine International Conference on Economics, Education, Humanities and Social Sciences. https://doi.org/10.17758/ERPUB3.UH0119421

Broad, K., \& Evans, M. (2006). A review of literature on professional development content and delivery modes for experienced teachers. Toronto, CAN: University of Toronto, Ontario Institute for Studies in Education. https://www.oise.utoronto.ca/guestid/ite/UserFiles/File/AReviewofLiteratureonPD.pdf

Borko, H. (2004). Professional development and teacher learning: Mapping the terrain. Educational researcher, 33(8), 3-15. https://doi.org/10.3102\%2F0013189X033008003

Bukoye, R. O. (2019). Utilization of Instruction Materials as Tools for Effective Academic Performance of Students: Implications for Counselling. In Multidisciplinary Digital Publishing Institute Proceedings (Vol. 2, No. 21, p. 1395). https://doi.org/10.3390/proceedings2211395

Burchell, H., Dyson, J., \& Rees, M. (2002). Making a difference: a study of the impact of continuing professional development on professional practice. Journal of inservice education, 28(2), 219-230. https://doi.org/10.1080/13674580200200180

Caingcoy, M. (2020). Research Capability of Teachers: Its Correlates, Determinants and Implication for Continuing Professional Development. Available at SSRN: https://ssrn.com/abstract=3631867 or http://dx.doi.org/10.2139/ssrn.3631867

Champion, R. (2003). Taking measure. The real measure of a professional development program's effectiveness lies in what participants learn. Journal of Staff Development, 24(1), 75-76

Cochran-Smith, M., \& Lytle, S. L. (2001). Beyond certainty: Taking an inquiry stance on practice. In A. Lieberman \& L. Miller (Eds.), Teachers caught in the action: Professional development that matters (pp. 45-61). New York, NY: Teachers College Press.

Day, C. (1997). In-service teacher education in Europe: Conditions and themes for development in the 21st century. In Anales de Pedagogía (No. 15).

Dillenbourg, P., Baker, M., Blaye, A., \& O'Malley, C. (1996). The evolution of research on collaborative learning. Dans P. Reimann \& H. Spada (éds.) Learning in Humans and Machines: Towards an Interdisciplinary Learning Science.

Elmore, R. F. (2002). Bridging the gap between standards and achievement: The imperative for professional development in education. Secondary lenses on learning participant book: Team leadership for mathematics in middle and high schools, 313-344.

Elmore, R. F. (2002). Bridging the gap between standards and achievement: The imperative for professional development in education. Secondary lenses on learning participant book: Team leadership for mathematics in middle and high schools, 313-344. https://books.google.com.ph/books?hl=en\&lr=\&id=x5FuyYd2cM4C\&oi=fnd\&pg=PA313\&dq=Elemore+(2002)+described+professional+development+ as+sustained+focus+over+time+that+is+consistent+with+best+practice.\&ots=MRns7qjXtT\&sig=XtG4z7LOz1mxsrwrCXgBxax70jo\&redir_esc=y\#v=on epage $\& \mathrm{q} \& \mathrm{f}=$ false

Esguerra, J. ( 1998). Writing quality research. UB Monograph Series No.3 Research development center, University of Baguio, Baguio City.

Fraser, J., Fahlman, D. (Willy), Arscott, J., \& Guillot, I. (2018). Pilot Testing for Feasibility in a Study of Student Retention and Attrition in Online Undergraduate Programs. The International Review of Research in Open and Distributed Learning, 19(1). https://doi.org/10.19173/irrodl.v19i1.3326

Frost,D.(2006). The concept of agency in leadership for learning. Journal of the Australian Council for Educational Leaders, 12(2), https://www.educ.cam.ac.uk/networks/lfl/projects/pastprojects/DF\%20art\%20Agency.pdf

Gonzalez,A. (2006). Creating a culture of research in a developing country.Bernardo, A.B.I.,Munoz, M.P.,\& Valencia, M.N (eds) Research and higher education development: Asia Pacific Perspectives. Manila: Lasallian Institute for Development and educational Research, College of Education, De La Salle University-Manila.

Goe, L., Biggers, K., \& Croft, A. (2012). Linking Teacher Evaluation to Professional Development: Focusing on Improving Teaching and Learning. Research \& Policy Brief. National Comprehensive Center for Teacher Quality. https://eric.ed.gov/?id=ED532775

Guskey, T. R. (1995). Professional development in action: New paradigms and practices. (T. R. Guskey\& M. Huberman, Eds.) New York: Teachers College Press.

Hannay, L. M., Seller, W., \& Telford, C. (2003). Making the conceptual shift: Teacher performance appraisal as professional growth. Educational Action Research, 11(1), 121-140. https://doi.org/10.1080/09650790300200204

Hoffman, A. and Holzhuter, J. (2012), “The evolution of higher education: innovation as natural selection”, in Hoffman, A. and Spangehl, S. (Eds), Innovation in Higher Education: Igniting the Spark for Success, American Council on Education, Rowman \& Litttlefield Publishers Inc., Lanham, MD, pp. 3-15.

Hord, S. M. (Ed.). (2004). Learning together leading together: Changing schools through professional learning communities. New York, NY: Teachers College Press.

Horn, I., Garner, B., Chen, I. C., \& Frank, K. A. (2020). Seeing colleagues as learning resources: The influence of mathematics teacher meetings on advice-seeking social networks. AERA open, 6(2), 2332858420914898. https://doi.org/10.1177\%2F2332858420914898 
Jonathan, L. (2016). The research capability of ilocos sur polytechnic state college: A basis for a capability enhancement program. International Journal of Management and Social Sciences Research, 5(7), 41-44.

Lacanaria, B. F. (2008). Faculty research in higher education institution: extent and hindering factors (Doctoral dissertation).

Leonard, L., \& Wibawa, B. (2020). A training model based on collaborative research to develop teachers' research competence. International Jurnal of Innovation, Creativity and Change, 12(10), 592-608. https://ijicc.net/images/vol12/iss10/121037_Leonard_2020_E_R.pdf

Mathew, P., Mathew, P., \& Peechattu, P. J. (2017). Reflective practices: A means to teacher development. Asia Pacific Journal of Contemporary Education and Communication Technology, 3(1), 126-131. ISBN: 9780 9943656 82; ISSN: 2205-6181

Manfra, M. M. (2019). Action research and systematic, intentional change in teaching practice. Review of Research in Education, 43(1), 163-196. https://doi.org/10.3102\%2F0091732X18821132

Miles, K. H., Olden, A., Fermanich, M., \& Archibald, S. (2004). Inside the blackbox of school spending on professional development: Lessons from comparing five urban districts. Journal of Education and Finance 30(1) 1-26.

Naz, F., \& Murad, H. S. (2017). Innovative teaching has a positive impact on the performance of diverse students. SAGE Open, 7(4), 2158244017734022.

National research Council (2001), Testing teacher candidates: The role of licensure test in improving teacher quality. Washington, DC: National Academy Press.

National Staff Development Council (2001). NSDC’s Standards for Staff Development. Oxford, OH. Author.

National Staff Development Council (2007). Professional development. Retrieved March 15, 2009, from http://www.NSDC.org/connect/about/index.cfm.

Nenty, H. J., Moyo, S., \& Phuti, F. (2015). Perception of Teaching as a Profession and UB Teacher Trainees' Attitude towards Training Programme and Teaching. Educational Research and Reviews, 10(21), 2797-2805. https://eric.ed.gov/?id=EJ1084157

Nunan, D. (1999). Second Language Teaching \& Learning. Heinle \& Heinle Publishers, 7625 Empire Dr., Florence, KY $41042-2978$.

OECD (2007). Evidence in education: Linking research policy. OECD. Publishing, Paris

Osamwonyi, E. F. (2016). In-Service Education of Teachers: Overview, Problems and the Way Forward. Journal of Education and Practice, 7(26), 83-87. https://eric.ed.gov/?id=EJ1115837

Pambuena, E. L., \& Bernarte, R. (2018). The Research Skills, Personal Effectiveness, Networking and Team Working, and Communication Skills of Polytechnic University of the Philippines Laguna Campuses Faculty: Basis for an Action Plan. KnE Social Sciences, 3(6), 339-359. https://doi.org/10.18502/kss.v3i6.2391

Pearson, J. A. (2016). Too Important to Ignore: A Post-Intentional Phenomenological Investigation of Teaching Pre-Service Early Childhood Teachers About Infants and Toddlers (Doctoral dissertation, University of Minnesota).

Postholm, M. B. (2018). Teachers professional development in school: A review study. Cogent education, 5(1), 1522781.https://doi.org/10.1080/2331186X.2018.1522781

Richardson, V. (2003). The dilemmas of professional development. SAGE Publication, 84(5), 401-406. https://doi.org/10.1177\%2F003172170308400515

Ross, J. A., \& McDougall, D. (2003). The development of education quality performance standards in grade 9-10 mathematics teaching. Peterborough, ON: OISE/UT Trent Valley Centre. https://legacy.oise.utoronto.ca/research/field-centres/TVC/rpts/tg02-03.pdf

Ross, J. A., \& Bruce, C. D. (2007). Teacher self-assessment: A mechanism for facilitating professional growth. Teaching and teacher Education, 23(2), 146-159. https://doi.org/10.1016/j.tate.2006.04.035

Salazars-Clemeña, R.M. 2006. Higher education research in the Philippines: policies, practices and problems. Meek, V.L. \& Suwanwela, C.(eds) Higher Education Research and Knowledge in the Asia Pacific Region (pp. 185-200) New York: Palgrave Macmillan.

Salom, M. (2013). Research capability of the faculty members of DMMMSU Mid La Union Campus. International Scientific Research Journal, 5(2), 45-55.

Segismundo, M. C. D. (2017). Measuring accreditation experience: Impact on the quality of education of selected ASAS Member-Schools In Luzon and the NCR. International Journal of Education and Research, 5(7).

Selvi, K. (2010). Teachers' competencies. Cultura International Journal of Philosophy of Culture and Axiology, 7(1), 167-175.

Serdyukov P, (2017) Innovation in education: what works, what doesn't, and what to do about it?. Journal of Research in Innovative Teaching \& Learning, 10 (1),4-33, ISSN: 2397-7604. https://doi.org/10.1108/JRIT-10-2016-0007

Showers,B \& Joyce, B. (1996). The evolution of peer coaching. 53(6), 12-16.

Singh, A. K., \& Singh, B. (2016). Professional development of teachers teaching in CBSE and UP board secondary schools. IJAR, 2(3), 687-694. https://web.archive.org/web/20180414085113id/http://www.allresearchjournal.com/archives/2016/vol2issue3/PartL/2-3-30.pdf

Smith,K., \& Lindsay, S. (2016). Building future directions for teacher learning in science education. Research in Science Education, 46,243-261. https://doi.org/10.1007/s11165-015-9510-x 
ISSN 2250-3153

Tucker, J. \& Fushell, M. (2013). Graduate programs in education: Impact on teachers' careers. Canadian Journal of Educational Administration and Policy, Issue \#148. https://files.eric.ed.gov/fulltext/EJ1017213.pdf

Van der Klink, M., Kools, Q., Avissar, G., White, S., \& Sakata, T. (2017). Professional development of teacher educators: What do they do? Findings from an explorative international study. Professional development in education, 43(2), 163-178. https://doi.org/10.1080/19415257.2015.1114506

Walling, B., \& Lewis, M. (2000). Development of professional identity among professional development school preservice teachers: Longitudinal and comparative analysis. Action in teacher Education, 22(sup2), 65-72. https://doi.org/10.1080/01626620.2000.10463040

Zepeda, S. J. (2013). Professional development: What works. Routledge. https://doi.org/10.4324/9781315854878

Zepeda, S.J. (2012). Professional Development: What Works (2nd ed.). Routledge. https://doi.org/10.4324/9781315854878 